\section{Reducing the conformational flexibility of carbohydrates: locking the 6-hydroxyl group by cyclopropanes $\nmid$}

\author{
Christian Brand, ${ }^{a}$ Markus Granitzka, ${ }^{b}$ Dietmar Stalke ${ }^{b}$ and Daniel B. Werz ${ }^{* a}$
}

Received 5th July 2011, Accepted 9th August 2011

DOI: $10.1039 / \mathrm{c} 1 \mathrm{cc} 14025 \mathrm{f}$

The 6-hydroxyl group of hexopyranosides was stereochemically locked by the spiroannelation of a cyclopropane unit at $\mathrm{C}-5$. The corresponding glucose and mannose derivatives were prepared and their behaviour in glycosidation reactions was studied.

Carbohydrates are important in a variety of intercellular recognition events including cell adhesion, viral infection and cancer metastasis. ${ }^{1}$ Therefore, carbohydrate mimetics are of paramount importance in order to fine-tune their biological behaviour. ${ }^{2} C$-Glycosides have been used to enhance the stability of the glycosidic bond, ${ }^{3}$ fluorinated carbohydrate derivatives were prepared due to their similar polarity in comparison with the native counterparts, ${ }^{4}$ hybrids of sugars and aromatics were prepared ${ }^{5}$ and iminosugars were often employed as enzyme inhibitors, ${ }^{6}$ just to name a few examples.

Only little work in the field of carbohydrate mimetics was devoted to pre-adjust specific conformations of mono- or oligosaccharides $^{7}$ although the conformation of sugars is of crucial importance for the hydrolysis of the glycosidic bond. ${ }^{8}$

In this communication we present our recent studies to lock the direction of the 6-hydroxyl group of pyranosides. To address this issue we made use of a spiroannelated three-membered ring at C-5 bearing one hydroxyl group (Fig. 1). ${ }^{9}$ The small cyclopropane ring in $\mathbf{2}$ has only a minimal impact on the structural integrity of
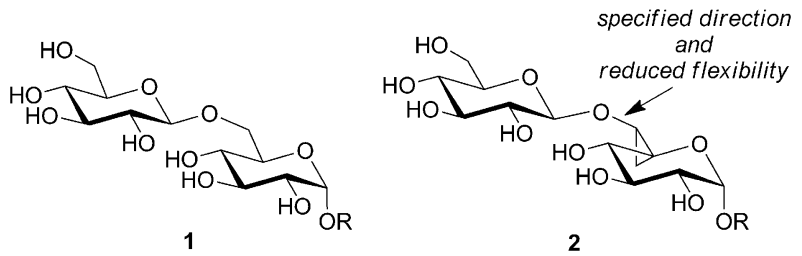

Fig. 1 Carbohydrate 1 with a flexible glycosidated 6-hydroxyl group and analogue $\mathbf{2}$ with reduced flexibility at the glycosidated 6-hydroxyl.

${ }^{a}$ Institut für Organische und Biomolekulare Chemie der Georg-August-Universität Göttingen, Tammannstr. 2, D-377077 Göttingen, Germany.E-mail: dwerz@gwdg.de;

Fax: + 49(551)399476; Tel: + 49(551)393251

${ }^{b}$ Institut für Anorganische Chemie der Georg-August-Universität Göttingen, Tammannstr. 4, D-377077 Göttingen, Germany

$\dagger$ Electronic supplementary information (ESI) available: Detailed experimental procedures, ${ }^{1} \mathrm{H}$ and ${ }^{13} \mathrm{C}$ NMR data, analytical data for all new compounds and crystallographic data for 33. CCDC 832491. For ESI and crystallographic data in CIF or other electronic format see DOI: $10.1039 / \mathrm{c} 1 \mathrm{cc} 14025 \mathrm{f}$

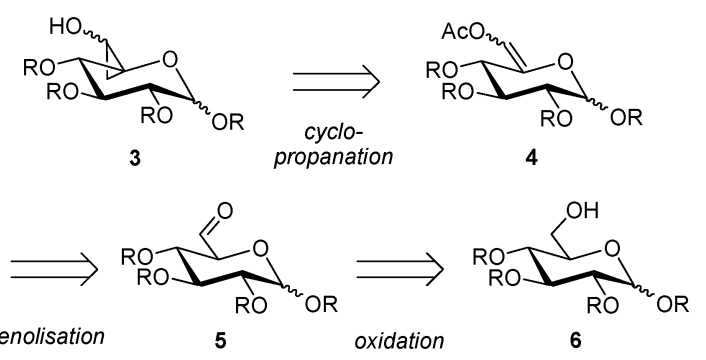

Scheme 1 Retrosynthetic analysis of monosaccharides of type $\mathbf{3}$ with a locked 6-hydroxyl group by a spiroannelated three-membered ring at C-5.

the carbohydrate, but specifies the direction of the hydroxyl group and thus reduces the rotational flexibility of the C6-O bond.

Our retrosynthetic considerations for hydroxycyclopropanated pyranosides are depicted in Scheme 1. The enol acetate $\mathbf{4}$ can be prepared in two steps from the corresponding monosaccharide $\mathbf{6}$ with an unprotected 6-hydroxyl group by oxidation to the respective aldehyde $\mathbf{5}$ and further enolisation followed by subsequent protection with acetate. Endo- and exocyclic enol ethers have previously been shown to be valuable substrates for cyclopropanation reactions. ${ }^{10}$

The starting point of our syntheses was methyl glucoside 7 that was subjected to a Swern oxidation followed by subsequent enolisation in acetic anhydride under the influence of potassium carbonate. ${ }^{11}$ Two diastereomeric enol acetates 8 and 9 were obtained in a ratio of $1: 8$ and could be separated by careful column chromatography. The electron-rich double bond allowed a cyclopropanation under Simmons-Smith-Furukawa conditions (Scheme 2). ${ }^{12}$

To our delight, we observed facial selectivity in the threemembered ring formation. This transformation allows access to the depicted products which result from a bottom-attack of the organometallic species, for both glucose-derived diastereomers $\mathbf{1 0}$ and 11 (Scheme 2). The corresponding cyclopropane derivatives resulting from a top-attack were observed in minor amounts only (see ESI $\dagger$ ). The configuration of all the diastereomers was determined by extensive 2D-NMR spectroscopy and NOESY investigations. Potassium carbonate in methanol gave access to the hydroxycyclopropane derivatives 12 and $\mathbf{1 3}$. Hydrogenolysis afforded the cyclopropanated methyl glucopyranosides 14 and 15, respectively.

Having found suitable reaction conditions for the glucose derivative, an analogous sequence was conducted for the 


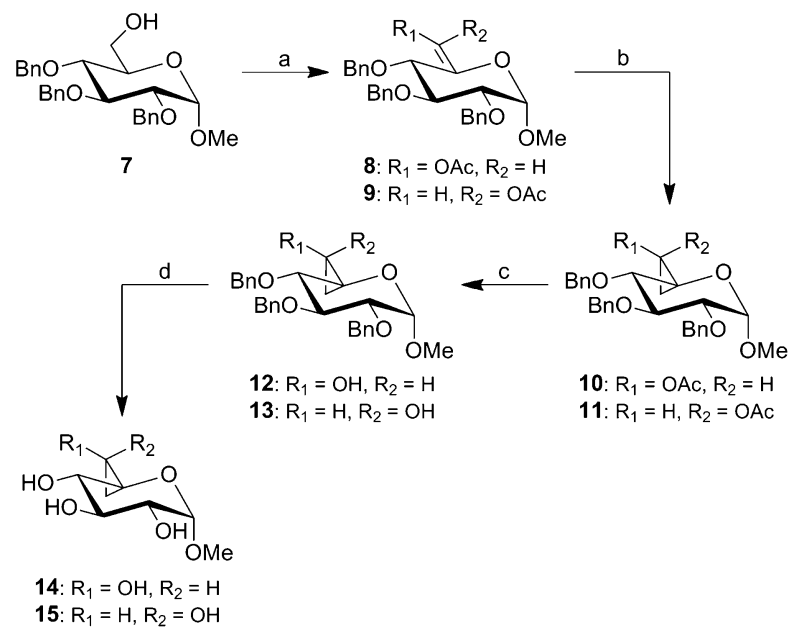

Scheme 2 Reagents and conditions: (a) 1. $(\mathrm{COCl})_{2}, \mathrm{DMSO}, \mathrm{Et}_{3} \mathrm{~N}$, $\mathrm{CH}_{2} \mathrm{Cl}_{2},-78{ }^{\circ} \mathrm{C} ; 2 . \mathrm{K}_{2} \mathrm{CO}_{3}, \mathrm{Ac}_{2} \mathrm{O}, \mathrm{CH}_{3} \mathrm{CN}$, reflux, $8(9 \%), 9(70 \%)$; (b) $\mathrm{ZnEt}_{2}, \mathrm{CH}_{2} \mathrm{I}_{2}, \mathrm{ClCH}_{2} \mathrm{CH}_{2} \mathrm{Cl}, 50{ }^{\circ} \mathrm{C}, \mathbf{1 0}(35 \%), 11(64 \%)$; (c) $\mathrm{K}_{2} \mathrm{CO}_{3}, \mathrm{MeOH} / \mathrm{H}_{2} \mathrm{O}$, rt, $12(77 \%), 13(55 \%)$; (d) $\mathrm{H}_{2}, \mathrm{Pd} / \mathrm{C}$, $\mathrm{MeOH} / \mathrm{CH}_{2} \mathrm{Cl}_{2} / \mathrm{EtOAc}, \mathrm{rt}, \mathbf{1 4}$ (quant.), 15 (quant.).
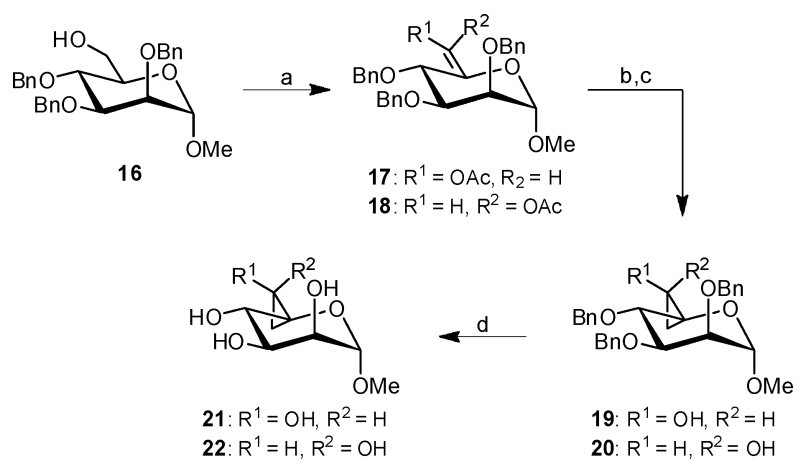

Scheme 3 Reagents and conditions: (a) 1. $(\mathrm{COCl})_{2}, \mathrm{DMSO}, \mathrm{Et}_{3} \mathrm{~N}$, $\mathrm{CH}_{2} \mathrm{Cl}_{2},-78{ }^{\circ} \mathrm{C} ; 2 . \mathrm{K}_{2} \mathrm{CO}_{3}, \mathrm{Ac}_{2} \mathrm{O}, \mathrm{CH}_{3} \mathrm{CN}$, reflux, $17(12 \%), 18$ (66\%); (b) $\mathrm{ZnEt}_{2}, \mathrm{CH}_{2} \mathrm{I}_{2}, \mathrm{ClCH}_{2} \mathrm{CH}_{2} \mathrm{Cl}, 50{ }^{\circ} \mathrm{C} \ddagger$; (c) $\mathrm{K}_{2} \mathrm{CO}_{3}, \mathrm{MeOH} /$ $\mathrm{H}_{2} \mathrm{O}, \mathrm{rt}, \mathrm{19}(54 \%), 20$ (46\%); (d) $\mathrm{H}_{2}, \mathrm{Pd} / \mathrm{C}, \mathrm{MeOH} / \mathrm{CH}_{2} \mathrm{Cl}_{2} / \mathrm{EtOAc}, \mathrm{rt}$, 21 (quant.), $22(69 \%)$.

corresponding mannose-derived enol ethers $\mathbf{1 7}$ and $\mathbf{1 8}$ (Scheme 3). ${ }^{11}$ Although the axial OBn-group in position 2 should hinder the attack of the methylene-transferring agent in the Simmons-Smith reaction we did not observe a better facial selectivity to yield $\mathbf{1 9}$ and $\mathbf{2 0}$ than in the case of glucose. The hydroxylated methyl mannosides $\mathbf{2 1}$ and $\mathbf{2 2}$ were obtained by saponification and subsequent hydrogenolysis.

With the cyclopropanated glucose and mannose derivatives 12, 13, 19 and 20 in hand, we investigated their behaviour in glycosidation reactions. Therefore, methyl glucopyranoside $\mathbf{1 2}$ with a free hydroxyl group at the cyclopropane moiety was reacted with perbenzoylated glucosyl trichloroacetimidate $\mathbf{2 3}^{\mathbf{1 3}}$ to form the pseudodisaccharide $\mathbf{2 4}$ in $\mathbf{7 1 \%}$ yield (Scheme 4). Global deprotection was accomplished by sodium methoxide in methanol to cleave the benzoates and treatment with $\mathrm{Pd} / \mathrm{C}$ under an atmosphere of hydrogen to remove all benzyl protecting groups. Analogous experiments were carried out with the respective diastereomer 13 and the mannose-derivatives 19 and 20 to afford disaccharide mimetics 27, 29 and 31, respectively (Scheme 5). The yields of the glycosylation range from

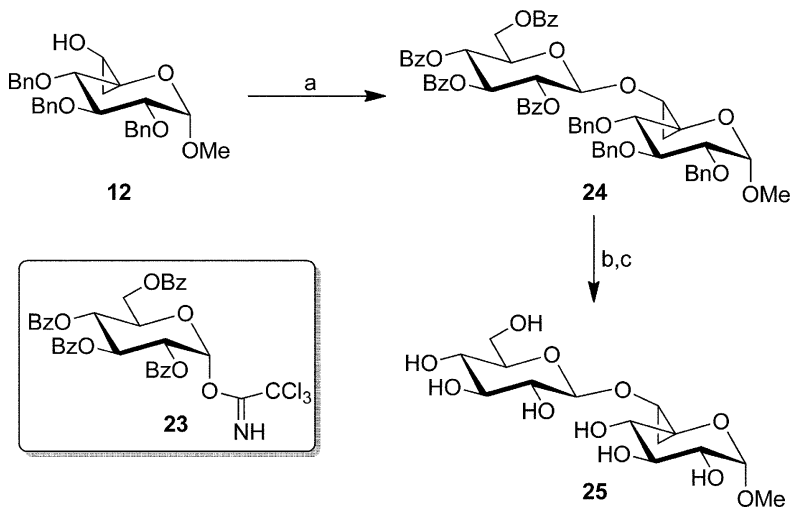

Scheme 4 Reagents and conditions: (a) 23, TMSOTf, $\mathrm{CH}_{2} \mathrm{Cl}_{2}, 0{ }^{\circ} \mathrm{C}$, $71 \%$; (b) $\mathrm{NaOMe} / \mathrm{MeOH}, \mathrm{MeOH}, \mathrm{rt}, 93 \%$; (c) $\mathrm{H}_{2}, \mathrm{Pd} / \mathrm{C}, \mathrm{MeOH} /$ $\mathrm{CH}_{2} \mathrm{Cl}_{2}$ /EtOAc, rt, quant.

$60-76 \%$. Both deprotection reactions, saponification as well as hydrogenolysis proceeded smoothly.

In order to elucidate whether the spiroannelated threemembered ring alters the conformation of the chair-like pyranose to a major extent we tried to get crystals of the
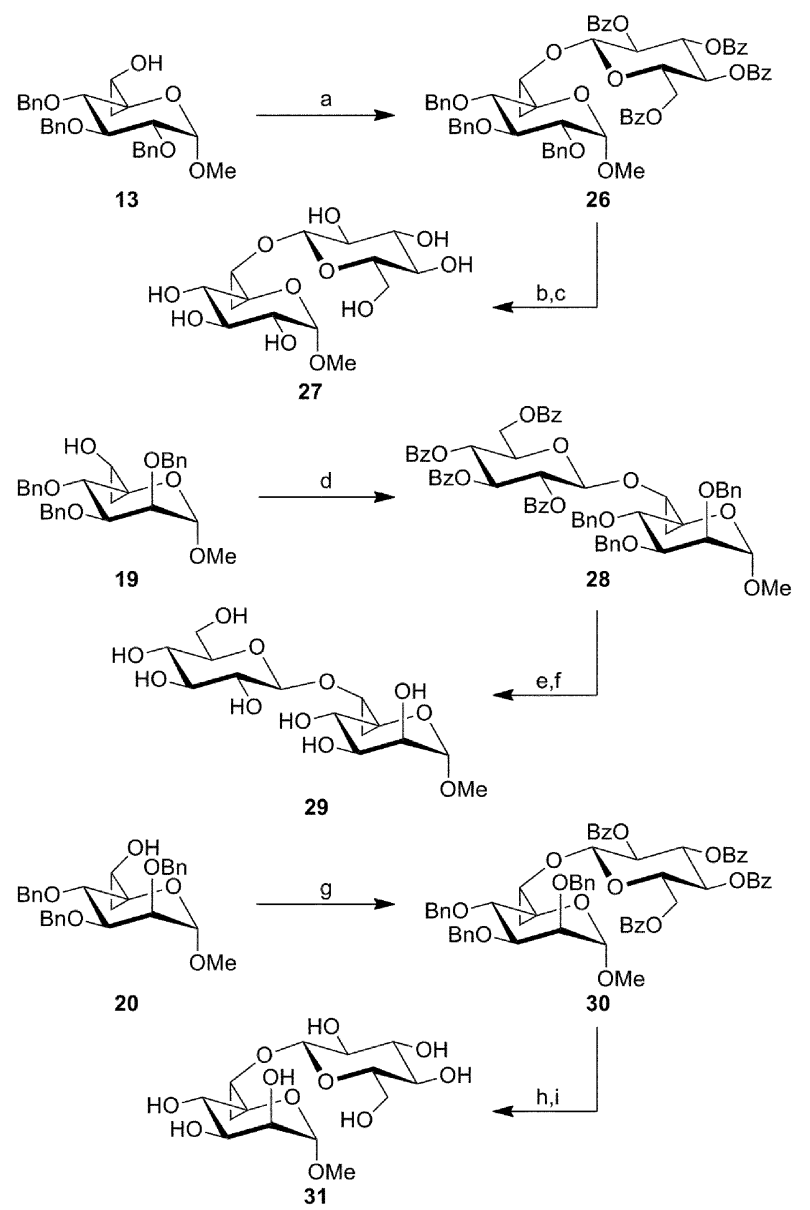

Scheme 5 Reagents and conditions: (a) 23, TMSOTf, $\mathrm{CH}_{2} \mathrm{Cl}_{2}, 0{ }^{\circ} \mathrm{C}$, $60 \%$; (b) $\mathrm{NaOMe} / \mathrm{MeOH}, \mathrm{MeOH}, \mathrm{rt}, 78 \%$; (c) $\mathrm{H}_{2}, \mathrm{Pd} / \mathrm{C}, \mathrm{MeOH} /$ $\mathrm{CH}_{2} \mathrm{Cl}_{2}$ /EtOAc, rt, quant; (d) 23, TMSOTf, $\mathrm{CH}_{2} \mathrm{Cl}_{2}, 0{ }^{\circ} \mathrm{C}, 76 \%$; (e) $\mathrm{NaOMe} / \mathrm{MeOH}, \mathrm{MeOH}, \mathrm{rt}, 77 \%$; (f) $\mathrm{H}_{2}, \mathrm{Pd} / \mathrm{C}, \mathrm{MeOH} / \mathrm{CH}_{2} \mathrm{Cl}_{2} /$ EtOAc, rt, quant. (g) 23, TMSOTf, $\mathrm{CH}_{2} \mathrm{Cl}_{2}, 0{ }^{\circ} \mathrm{C}, 60 \%$; (h) $\mathrm{NaOMe} /$ $\mathrm{MeOH}, \mathrm{MeOH}, \mathrm{rt}, 94 \%$; (i) $\mathrm{H}_{2}, \mathrm{Pd} / \mathrm{C}, \mathrm{MeOH} / \mathrm{CH}_{2} \mathrm{Cl}_{2} / \mathrm{EtOAc}$, rt, $98 \%$. 


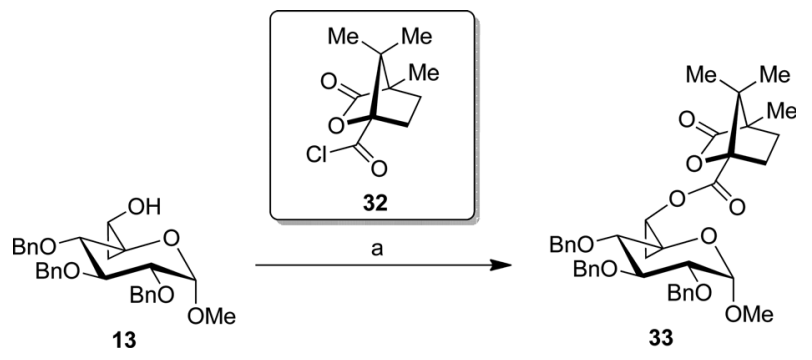

Scheme 6 Reagents and conditions: (a) 32, pyridine, DMAP, $\mathrm{CH}_{2} \mathrm{Cl}_{2}$, $0{ }^{\circ} \mathrm{C}, 80 \%$.

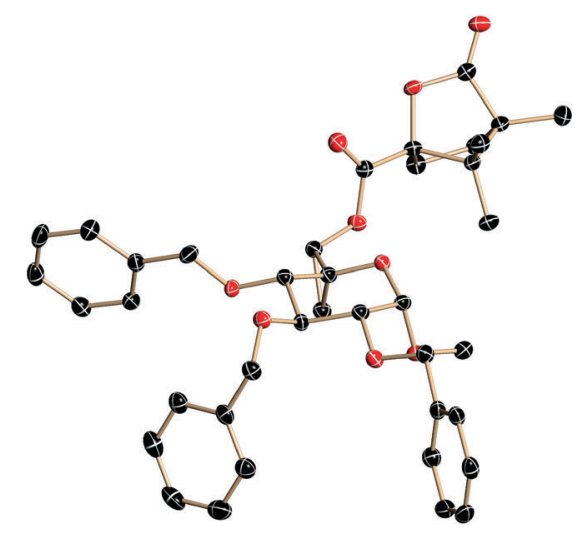

Fig. 2 Molecular structure of the camphor-derived cyclopropanated glucopyranoside 33. Anisotropic displacement parameters are depicted at $50 \%$ probability level. Hydrogen atoms are omitted for the sake of clarity. Oxygen atoms are shown in red. ${ }^{15}$

respective cyclopropane derivatives such as 12-15. However, all these experiments proved to be unsuccessful. Therefore, compound 13 was transformed with (-)-camphanic acid chloride (32) in pyridine to the respective camphanoyl ester 33 (Scheme 6). ${ }^{14}$

With this compound we were able to grow single crystals suitable for X-ray analysis. $\dagger$ The molecular structure of $\mathbf{3 3}$ in the solid state $^{15}$ is depicted in Fig. 2. Although slightly distorted, the general chair-like conformation of the six-membered ring is preserved. The hydroxyl groups at positions 2-4 are equatorial, because of the stiffness of the cyclopropane the 6-hydroxyl adopts a distinct position.§ Stereochemical flexibility as in common glucose does not exist any more.

In conclusion, we have developed an approach to reduce the conformational flexibility of the 6-hydroxyl group of pyranosides. The key to attain this goal is a spiroannelation of a hydroxycyclopropane at C-5 of the monosaccharide. This structural feature was accessed by the Simmons-Smith-Furukawa reaction of the corresponding enol ether acetates. The resulting cyclopropanated monosaccharides with a free hydroxyl group at the three-membered ring were smoothly glycosidated with glycosyl trichloroacetimidates. Extension of this approach to other monosaccharide units as well as an incorporation of this structural motif into glycosyl donors and then in larger oligosaccharides is in progress. The respective mimetics might be of great value for biochemical and medicinal studies.
We are grateful to the Deutsche Forschungsgemeinschaft (Emmy Noether Fellowship to D.B.W.), the Fonds der Chemischen Industrie (Liebig Fellowship to D.B.W.) and to BASF Aktiengesellschaft for the donation of chemicals. We are also grateful to the DNRF funded CMC for funding (D.S., M.G.) Furthermore, we thank Prof. Dr Lutz F. Tietze for helpful discussions and generous support of our work.

\section{Notes and references}

$\ddagger$ Separation of the two diastereomers was only possible after acetate removal. Yield for the cyclopropanation reaction, see ESI $\dagger$.

$\S$ Crystal data for 33 at $100(2) \mathrm{K}: \mathrm{C}_{39} \mathrm{H}_{44} \mathrm{O}_{9}, M_{\mathrm{r}}=656.74,0.2 \times$ $0.06 \times 0.06 \mathrm{~mm}$, monoclinic, $P 2_{1}, a=6.249(2), b=16.225(3), c=$ 16.620(3) $\AA, \beta=91.93(2), V=1684.1(7) \AA^{3}, Z=2, \rho_{\text {calcd }}=$ $1.295 \mathrm{Mg} \mathrm{m}^{-3}, \mu(\mathrm{Mo} \mathrm{K} \alpha)=0.091 \mathrm{~mm}^{-1}, 2 \theta_{\max }=55^{\circ}, 39222$ reflections measured, 4052 independent $\left(R_{\text {int }}=0.0459\right), R_{1}=0.031$ $(I>2 \sigma(I)), \mathrm{w} R_{2}=0.0760$ (all data), res. density peaks: 0.198 to -0.156 e $\AA^{-3}$.

1 (a) P. H. Seeberger and D. B. Werz, Nature, 2007, 446, 1046-1051; (b) R. A. Dwek, Chem. Rev., 1996, 96, 683-720; (c) L. A. Lasky, Science, 1992, 258, 964-969; (d) D. B. Werz and P. H. Seeberger, Chem.-Eur. J., 2005, 11, 3194-3206; (e) P. H. Seeberger and D. B. Werz, Nat. Rev. Drug Discovery, 2005, 4, 751-763.

2 (a) D. C. Koester, A. Holkenbrink and D. B. Werz, Synthesis, 2010, 3217-3242; (b) P. Sears and C.-H. Wong, Angew. Chem., Int. Ed., 1999, 38, 2300-2324.

3 (a) B. Giese, M. Hoch, C. Lamberth and R. R. Schmidt, Tetrahedron Lett., 1988, 29, 1375-1378; (b) M. H. D. Postema, J. L. Piper, V. Komanduri and L. Liu, Angew. Chem., Int. Ed., 2004, 43, 2915-2918; (c) D. C. Koester, M. Leibeling, R. Neufeld and D. B. Werz, Org. Lett., 2010, 12, 3934-3937.

4 (a) D. Crich and O. Vinogradova, J. Am. Chem. Soc., 2007, 129, 11756-11765; (b) S. Wagner, C. Mersch and A. Hoffmann-Röder, Chem.-Eur. J., 2010, 16, 7319-7330.

5 M. Leibeling, D. C. Koester, M. Pawliczek, S. C. Schild and D. B. Werz, Nat. Chem. Biol., 2010, 6, 199-201.

6 P. Compain and O. R. Martin, Iminosugars from synthesis to therapeutical applications, John Wiley \& Sons: Hoboken, 2007.

7 (a) L. F. Tietze, H. Keim, C. O. Janßen, C. Tappertzhofen and J. Olschimke, Chem.-Eur. J., 2000, 6, 2801-2808; (b) H. H. Jensen, L. U. Nordstrøm and M. Bols, J. Am. Chem. Soc., 2004, 126, 9205-9213.

8 D. J. Vocadlo and G. J. Davies, Curr. Opin. Chem. Biol., 2008, 12, 539-555.

9 Spiroannelated cyclopropanes without hydroxyl groups were synthesized before: C. Bluechel, C. V. Ramana and A. Vasella, Helv. Chim. Acta, 2003, 86, 2998-3036.

10 (a) C. Brand, G. Rauch, M. Zanoni, B. Dittrich and D. B. Werz, J. Org. Chem., 2009, 74, 8779-8786; (b) T. F. Schneider, J. Kaschel, B. Dittrich and D. B. Werz, Org. Lett., 2009, 11, 2317-2320.

11 H. Takahashi, H. Kittaka and S. Ikegami, J. Org. Chem., 2001, 66, 2705-2716.

12 (a) H. E. Simmons and R. D. Smith, J. Am. Chem. Soc., 1959, 81, 4256-4264; (b) J. Furukawa, N. Kawabata and J. Nishimura, Tetrahedron, 1968, 24, 53-58; (c) J. Furukawa, N. Kawabata and J. Nishimura, Tetrahedron Lett., 1966, 7, 3353-3354; (d) Z. Song, T. Lu, R. P. Hsung, Z. F. Al-Rashid, C. Ko and Y. Tang, Angew. Chem., Int. Ed., 2007, 46, 4069-4072.

13 (a) K. Egusa, S. Kusumoto and K. Fukase, Eur. J. Org. Chem., 2003, 3435-3445; (b) R. R. Schmidt, J. Michel and M. Roos, Liebigs Ann. Chem., 1984, 1343-1357.

14 D. Enders, C. Wang and J. W. Bats, Angew. Chem., Int. Ed., 2008, 47, 7539-7542.

15 (a) T. Kottke and D. Stalke, J. Appl. Crystallogr., 1993, 26, 615; (b) Bruker, SAINT V7.68A., Bruker AXS Inc., Madison (WI, USA), 2005; (c) G. M. Sheldrick, SADABS 2008/2, Göttingen, 2008; (d) G. M. Sheldrick, Acta Crystallogr., Sect. A: Found. Crystallogr., 2008, 64, 112-122. 